\title{
Implementing Plurilingualism in Higher Education: Teacher Training Needs and Plan Evaluation
}

\author{
María del Mar SÁNChez PÉrez \\ María Sagrario Salaberri Ramiro \\ University of Almeria
}

Recibido: 01 mayo 2017 / Aceptado: 25 julio 2017

ISSN: 1697-7467

\begin{abstract}
The incorporation to the European Higher Education Area (EHEA) has given rise to an increase of the level of internationalisation of Spanish universities. Consequently, numerous institutions have started to implement plurilingual plans in order to increase their academic offer in a foreign language, mainly in English. The implementation of these plans requires the design and development of teacher training programs that enable teachers to improve their linguistic and methodological competence. This study aims to analyse the teacher training needs for plurilingual teaching at a state university in Andalusia (Spain) and describe the teacher training programme on plurilingual teaching methodologies implemented at this university during three academic years. Furthermore, the development of the Plurilingualism Promotion Plan implemented at the said university from 2012 to 2015 will be evaluated through a descriptive analysis of 16 indicators related to institutional strategy, internationalization of the curriculum and teaching staff. The results show a positive development of the analysed elements.
\end{abstract}

Keywords: Plurilingualism, internationalisation, language policy, higher education, teacher training.

Implementación del Plurilingüismo en Educación Superior: Necesidades de Formación del Profesorado y Evaluación del Plan

RESUMEN: La incorporación al Espacio Europeo de Educación Superior (EEES) ha dado lugar a un incremento del nivel de internacionalización de las universidades españolas. Como consecuencia, numerosas instituciones han comenzado a poner en marcha planes plurilingües con objeto de incrementar su oferta académica en una lengua extranjera, principalmente en inglés. La implementación de estos planes requiere el diseño y desarrollo de programas de formación docente que permitan a los profesores mejorar su competencia lingüística y metodológica. Este estudio tiene como objetivo analizar las necesidades de formación del profesorado en materia de enseñanza plurilingüe en una universidad pública de Andalucía (España), así como describir el programa de formación del profesorado sobre metodologías docentes en contextos plurilingües desarrollado en esta misma universidad durante tres cursos académicos. Asimismo, se proporciona una evaluación del desarrollo de un Plan de Promoción del Plurilingüismo implementado en la misma universidad mediante un análisis descriptivo de 16 indicadores relativos a la estrategia institucional, internacionalización del currículo y personal docente, durante el periodo comprendido entre 2012 y 2015. Los resultados muestran una evolución positiva de los elementos analizados.

Palabras clave: Plurilingüismo, internacionalización, política lingüística, educación superior, formación del profesorado 


\section{INTRODUCTION}

The current higher education system is characterised by an increasing diversity, interconnectivity and international mobility. Within this context, many post-secondary education institutions have been bound to increase their international profile and academic offer (Varghese, 2008; Weber and Dudesrstadt, 2008). As a consequence of this process, the number of plurilingual and English-medium instruction (EMI) degree programmes has grown significantly in Spanish universities during the last few years becoming a new trend within the Bologna system (Doiz, Lasagabaster and Sierra, 2013; Fortanet, 2013; Pérez-Vidal, 2014).

In contrast to what occurs in earlier educational stages, in which the implementation and development of bilingual and plurilingual programmes are officially regulated by the regional governments (cf. Junta de Andalucia, 2005), in higher education there are no officially regulated guidelines; therefore, such development becomes a complex challenge for university administrators and authorities. On the other hand, the quick implementation of plurilingual plans requires the design and development of teacher training programmes that enable lectures to cope with the appropriate methodologies adapted to the needs required by the plurilingual courses (Pavón and Gaustad, 2013). Although some universities are increasingly offering teaching staff with opportunities to improve their language skills, most have not been explicitly trained in specific educational methodologies to be used in plurilingual teaching contexts (Coyle, Hood and Marsh, 2010). On the contrary, plurilingual teaching at university level is usually performed in a "rather casual manner" (Costa and Coleman, 2010: 26); consequently, a desperate need of new methodological and teaching techniques has arisen among the teaching community (Salaberri and Sánchez-Pérez, 2012).

The aim of this study is to analyse the teacher training needs of the faculty participating in Plurilingualism Promotion Plan implemented at a state university in Andalusia (Spain), as well as to describe the teacher training program on plurilingual methodologies carried out at this university. Likewise, an evaluation of the development of the Plan implemented at this institution as a result of a bottom-up process will be provided by means of a descriptive analysis according to 16 indicators concerning institutional strategy, internationalisation of the curriculum and teaching staff, from 2012 to 2015 . This study is potentially useful for university regional and national policymakers in the field of language policies as it provides interesting data on the implementation of a pioneer plurilingualism promotion plan in a Spanish university.

\section{Theoretical Background}

\subsection{Plurilingual education at tertiary level}

The incorporation to the EHEA and the university reform resulting from the Bologna process has forced Spanish universities to give greater importance to language teaching. Due to the difficulty of ensuring a language continuous training to all students of all specialties through the inclusion of foreign language courses in university curricula, many universities have decided to implement bilingual and plurilingual programmes, in which disciplinary 
contents are taught through the medium of a foreign language, mainly English. This teaching modality, increasingly demanded by young people, who are aware of the importance of foreign language proficiency for their professional development, becomes a powerful argument for many institutions to achieve higher levels of competitiveness which will enable them to attract both national and international students, and, therefore, to strengthen their international profile.

Language is at the core of the internationalisation process (Grimshaw, 2007). Apart from the multilingual environment created by student and staff mobility, universities are actively engaged in creating opportunities for members to learn foreign languages. In fact, the recent Erasmus+ initiative launched by the European Commission, in January 2015, within the framework of the Europe 2020 strategy, puts multilingualism and language learning at the core of its main objectives (European Commission, 2015: 13):

Multilingualism is one of the cornerstones of the European project and a powerful symbol of the EU's aspiration to be united in diversity. Foreign languages have a prominent role among the skills that will help equip people better for the labour market and make the most of available opportunities.

Despite the widespread indistinct use of the terms plurilingualism, bilingualism and multilingualism, there are some differences reported among these concepts that should be considered. In general terms, the concept of plurilingualism concerns the study of individuals' repertoires and agency in several languages (Gonçalves, 2011). In contrast, bilingualism and multilingualism refer to the communities or societies in which two or more different languages, respectively, are spoken (Baker, 2006; Moore \& Gajo, 2009). As the Council of Europe (2001) clarifies through the Common European Framework of Reference for Languages (CEFR), multilingualism refers to the coexistence of several languages in the same field and the same level, while plurilingualism is the knowledge of several languages by the same individual or group of people. The first requires a political decision and affects institutions, while plurilingualism describes a fact subordinated to different causes, whether natural (home, family) or acquired (language learning) and affects the individual. Such difference is explained by the Council of Europe (2001: 4) as follows:

Plurilingualism differs from multilingualism, which is the knowledge of a number of languages, or the co-existence of different languages in a given society. (...) the plurilingual approach emphasises the fact that as an individual person's experience of language in its cultural contexts expands, from the language of the home to that of society at large and then to the languages of other peoples (whether learnt at school or college, or by direct experience) (...).

Hence the difference when adopting a pluriligual or a bilingual or multilingual plan. While the last two aim to encourage students to learn two or more foreign languages, the purpose of the plurilingual plans go beyond and emphasize the expansion of the students' language experience in its cultural contexts so that they do not keep the these languages and cultures in "strictly separated mental communicative compartments" (Council of Europe, 2001: 4). In this sense, the goal of plurilingual plans is not only that students achieve mastery in two or more foreign languages in an isolated way, but to provide them with opportunities to 
develop both their linguistic and cultural repertory. European and Spanish universities are, therefore, creating strategies to prepare students for developing skills addressed to manage in international environments, through the promotion of the use of different languages in classrooms.

More than a decade ago, plurilingualism was marked as the main principle to achieve this goal, supported by the language and educational policies of the Council of Europe (CE). In fact, in its 2004-2005 action plan to promote language learning and linguistic diversity, the $\mathrm{CE}$ recommended universities to implement coherent language policies clarifying its role in encouraging language learning and linguistic diversity and stimulating all students to learn languages and offer them the possibility of studying abroad (Council of Europe, 2003). However, in most Spanish universities, language acquisition has not been a priority until last decade (Ballesteros, 2009). It has been recently that Spanish higher education institutions have implemented plurilingual degree programmes according to the rules, strategies and priorities of the universities themselves, which have become a complex challenge for university administrators and authorities.

Paradoxically, the Spanish Royal Decree 1393/2007, of 29th October, which establishes the ordering of official university education, requires obtaining a certified B1 foreign language level, according to the Common European Framework of Reference for Languages (CEFR). Language competence, a generic competence common to all university study plans, is included among the aims of many degrees, but few or no ECTS are allocated to subjects related to language learning in most non-linguistic-related areas.

In order to overcome this precarious language teaching and learning situation, The European Council, in an attempt to achieve the goals established and turn higher education institutions into multilingual universities for a multilingual Europe open to the world (Nancy Declaration, 2006), advocates for the introduction of lessons based on content and language integrated learning (CLIL) approaches in university curricula, which has being made by many Spanish universities in recent years.

\subsection{Plurilingual approaches in higher education}

The guidelines of the EHEA addressing the focus on higher education institutions towards internationalisation have led to an increasing need to introduce one or more foreign languages - mainly English - in university classrooms of all disciplines. This is mostly developed by the adoption of different approaches such as CLIL and English-medium Instruction (EMI), due to the increasing hegemony of English in international teaching and research across the globe (Altbach and Knight, 2007; Grimshaw, 2007; Pinto and Araújo e Sá, 2015; Van Damme, 2001).

Despite the widespread implementation of EMI programmes in Spanish universities, the CLIL approach is considered as one of the most innovative approaches in the field of foreign - language teaching and learning (Arnold, 2010) at this educational level, due to the multiple advantages that it offers at a linguistic, psychological, pedagogical or institutional level, as many studies attest (Lasagabaster and Ruiz de Zarobe, 2010; Lorenzo, Casal and Moore, 2010; Madrid and Hughes, 2011). Apart from the language restrictive focus of the EMI approach, there are other substantial conceptual and methodological differences between both approaches. EMI mainly focuses on content learning and little or no special attention 
is paid to language learning (Smit and Dafouz, 2012) ${ }^{1}$. According to Morgado \& Coelho (2013), CLIL is seen as a more flexible solution to students and lecturers' needs as well as more effective and inclusive for students with weaker foreign language abilities. According to these authors, CLIL appears as a compensatory strategy to work on the foreign language skills of students in HE when there is no adequate language provision in university curricula or when the students' language skills are low; while EMI seems to constitute a practice introduced under internationalisation pressures and the presence of many international students, with poor results in terms of teaching and learning.

The CLIL concept in higher education contexts has often been used as an umbrella term for very different teaching approaches, from total and partial immersion to simply foreign - language-medium instruction. However, the CLIL notion with reference to tertiary level has been acquiring different connotations. Firstly, it has been used to refer to different approaches, such as, Language for Specific Purposes (LSP) or sheltered instruction, which share the use of content to teach language or provide language support for courses that are run parallel to content courses (Coyle et al. 2010; Snow and Brinton, 1997). Secondly, it has been used to refer to teaching subjects in foreign languages where language support is provided simultaneously (Hellekjaer and Wilkinson, 2001) or, to "any dual-focused educational context in which an additional language (...) is used as a medium in the teaching and learning of non-language content" (Marsh, 2002: 15). Finally, it has been used with reference to the instruction of subjects in a foreign language without any language support or language sensitive teaching methodologies (Vilkancienè, 2011).

In an attempt to define this particular approach specifically devoted to higher education, different labels have arisen, such as CLIL itself (Dalton-Puffer, Nikula and Smit, 2010), Integrating Content and Language in Higher Education, ILCHE, (Wilkinson and Zegers, 2007), English-medium teaching (Coleman, 2006) or English-medium instruction (EMI), and, more recently, Integrating Content and Language, ICL (Smit and Dafouz, 2012) or EnglishMedium Education in Multilingual University Settings, EMEMUS (Dafouz and Smit, 2016).

Although the CLIL approach has been the most renowned term at most educational levels (Smit and Dafouz, 2012), CLIL - and ICLHE - are mainly focalized on the fusion of both, explicit subject content and language learning aims (Coyle et al., 2010). Therefore, those practices lacking such pedagogical teaching aims "would not fall into prototypical CLIL or ICLHE programmes" (Smit and Dafouz, 2012: 4).

\subsection{Plurilingualism widespread across Spanish universities}

In Spanish universities, the number of bilingual Bachelor and Master's degree programmes has rapidly increased in the last few years following the guidelines of the EHEA. Spain has more than 70 universities, including both private and state institutions (Ramos, 2013), among which, there are more than 30 bilingual and plurilingual degree programmes (Dafouz and Nuñez, 2009). Most of them belong to Business and Engineering studies.

Instances of bilingual and plurilingual practices in higher education are increasingly being attested by literature. Among some of the works conducted in Spain, it is worth mentioning

\footnotetext{
${ }^{1}$ In view of the complexity of the matter, these authors preferred to use the terms Integrating Content and Language or ICL and EMI together (EMI/ICL) in a complementary manner in an attempt to come to terms with the terminological dilemma.
} 
the following projects: UCM-CLUE at the Universidad Complutense de Madrid (Dafouz et al., 2007), UAM-CLIL, at the Universidad Autónoma de Madrid (Llinares and Whittaker, 2006), DALE-APECS, at the Universitat Autònoma de Barcelona (Escobar and Nussbaum, 2011), or those conducted at the University of the Basque Country (Lasagabaster, 2013).

With regard to monolingual southern communities, such as Andalusia, most research attested by literature focuses mainly on primary or secondary education (Lorenzo et al., 2010; Pavón and Rubio, 2010; Salaberri and Sánchez-Pérez, 2012). With regard to plurilingual development and teacher training needs in higher education, some studies are found in settings such as the Universities of Almería (Manzano, Sánchez-Pérez and Salaberri, 2012; Sánchez-Pérez and Manzano, 2012), Jaén (Pérez-Cañado, 2013), Córdoba (Pavón and Gaustad, 2013) or Huelva, through the research project AGCEPESA, (Rubio and Hermosín, 2010; Toledo, Rubio and Hermosín, 2012), among others. This study complements the previous works by providing data on a plurilingual plan and teacher training development in an Andalusian university.

\subsection{Teacher training for plurilingual teaching in higher education}

An important condition to implement a pluirilingual policy in higher education, as in any other educational level, is the development of teacher training programmes that offer instructors the resources and tools that guarantee teaching success and act as support in the performing process. As stated by Smit and Dafouz (2012), these programmes should range from foreign language improvement to content-based teaching, considering that tertiary teaching staff members are mainly researchers who have hardly received any pedagogical training. In fact, teacher qualification has been considered a major issue in the appropriate development of plurilingual programmes at university.

As argued by some authors (Pavón and Gaustad, 2013; Smith, 2004), some of the main concerns typically found at universities implementing bilingual programmes, are, among others, the insufficient L2 proficiency of the teaching staff and their lack of training on methodological approaches, strategies and techniques specifically oriented to the teaching of disciplinary content through a non-native language. Despite the fact that some institutions are increasingly offering teaching staff with opportunities to improve their language proficiency through language courses, most of them have not been explicitly trained in specific educational methodologies to be used in plurilingual teaching contexts (Coyle et al., 2010). To this respect, the quick implementation of these programmes has caught lecturers unaware in the adoption of methodologies adapted to the needs required by the plurilingual education plans. Consequently, a strong demand of new methodological and teaching techniques has arisen among the teaching community (Salaberri and Sánchez-Pérez, 2012).

As Coyle et al. (2010: 24) state, in some countries, university teaching and research staff have not been explicitly trained in educational methodologies. In these cases, higher education has been viewed as characterized by transactional modes of educational delivery "(largely imparting information)", rather than the interactional modes "(largely processoriented)", which may hinder the possibilities of benefit from bilingual approaches. Bilingual and plurilingual teaching at university level is usually performed in a "rather casual manner" (Costa and Coleman, 2010: 26) due to the fact that professors and lecturers are not inclined to receive training on how to teach in a foreign language. Teacher training specially addressed

\section{4}


to university faculty would be essential so that lecturers could make the most of the potential of the plurilingual teaching approaches (Aguilar and Rodríguez, 2012).

These issues, as in most Spanish universities implementing bilingual and plurilingual programmes, are also found at the University of Almería, where the present study takes place. However, in order to overcome some of these difficulties, some measures have been taken, mainly regarding the difficulties found by the teaching staff, as will be explained in the next section.

\section{Methodology}

\subsection{Context of study}

The present study takes place at the University of Almeria (UAL), a state university of the region of Andalusia (South-East Spain). This university launched a Plurilingualism Promotion Plan with the aim to continue the policies regulating bilingual education at earlier educational stages in Andalusia, such as primary and secondary education (Junta de Andalucía, 2005). This Plan was approved by the University Government Council in February, 2009 , which allowed that different courses from all the degrees offered by the institution were taught in a language different from Spanish. Coordinated by the Vice-Chancellorship of Internationalisation and Cooperation for Development, it is considered a pioneer project among Andalusian higher education institutions aimed at promoting language learning among the students and staff (Manzano et al., 2012).

Since its first call in 2009, courses from more than 90 Undergraduate and Master's degree programmes (over 400 ECTS) are currently being taught in a foreign language, mainly in English. Albeit the Plan was initially open to any foreign language different from Spanish - in fact, during the first years of implementation some ECTS of certain undergraduate and postgraduate degrees were taught in languages such as French or German - during the years of analysis, English was the only foreign language used by the university lecturers participating in the Plan.

\subsection{Structure of the Plan}

All lecturers at the University of Almería are allowed to participate in the Plan. In order to guarantee continuity, a 3-year commitment is required for both the teaching staff involved and the Department they belong to. Among the requirements necessary to participate, the following can be highlighted:

- Teachers must certify a minimum B2 language level, according to CEFR. Those who do not own an official accreditation must pass a language examination and an interview specially designed by the University Language Centre.

- All participants must attend a 30-hour seminar on Methodology in Content and Language integrated Learning (CLIL) in higher education every year, whose contents include a series of lectures concerning teaching strategies in foreign language and CLIL, lesson design, adaptation of teaching materials, integrated curriculum, and intercultural skills to be applied in university lectures. 
The University of Almeria, aware of the great challenge for lecturers engaging in such hard task, includes a series of compensations for the teaching staff involved aimed to motivate the academic community to join the Plan. Among these compensations, the following can be mentioned:

1. ECTS reduction.

2. An economic grant to improve both language and methodological skills.

3. Priority in the creation of course groups ${ }^{2}$.

4. Recognition in the Assessment Programmes of professors' teaching activity (DOCENTIA), managed by the Spanish Agency for Higher Education Quality Assessment and Accreditation (ANECA).

5. Certificate issued by the Vice-Chancellor of Internationalisation attesting the teaching in a foreign language.

In order to monitor the implementation and development of the Plan, a quality survey is conducted every four years by the Quality Service of the University.

\subsection{Objectives and instruments for analysis}

As explained in the introduction of this paper, the goal of this study is twofold:

1. To analyse the teacher training needs of the faculty participating in a Plurilingualism Promotion Plan at a state university in Andalusia (Spain) and describe the teacher training programme on plurilingual teaching methodologies implemented at this university.

2. To evaluate the development of a Plurilingualism Promotion Plan implemented at the said university from 2012 to 2015 .

In order to fulfil the first objective, a questionnaire was conducted to 30 faculty members involved in the Plan to collect data about their training needs during three academic years. Based on their answers, a specific training program on plurilingual teaching methodologies was designed, as will be observed in the results section.

To achieve the second objective, a longitudinal descriptive study with two measurements was carried out, one during the academic year 2011/2012 and another one during the academic year $2014 / 2015$ by means of a questionnaire. It included 16 indicators concerning institutional strategy, internationalisation of the curriculum and teaching staff, and it was completed by the staff of the Vice-Chancellorship of Internationalisation. The study was conducted with the approval of the agents responsible for the Plurilingualism Promotion Plan of the University of Almería at that time, in particular, the Vice-Chancellor for Internationalisation. Once the data were received, different analyses were carried out using the statistical package IBM ${ }^{\circledR}$ SPSS 22 . The descriptive analyses that were performed include percentages and exchange rates.

\footnotetext{
${ }^{2}$ The minimum number of students for a group to be created is 10 . However, those courses participating in the Plan are allowed to be created with fewer students.
} 
María del Mar Sánchez and María Sagrario Salaberri Implementing Plurilingualism in Higher...

\section{Results}

\subsection{Results of the design of the teacher training programme}

With regard to the teacher training needs analysis, the results of the questionnaire 3 are represented in Figure 1, which shows that teachers demanded training in the use of the foreign language, with a particular focus on oral skills rather than written skills. In fact, both reading and writing represent $2 \%$ and $4 \%$ respectively, the lowest scores achieved. Training in oral communication reached the highest scores: listening (15\%), oral interaction $(13 \%)$ and oral classroom language $(15 \%)$, which represents nearly half of the respondents $(43 \%)$. In relation to teaching methodology, staff members do not attach much relevance to the use of digital devices (4\% and 5\% in questions 10 and 11, respectively). However, they are interested in training on material design $(9 \%)$ and specific teaching techniques related to the subject they teach $(13 \%)$.

Figure 1. Training needs of the teaching staff.

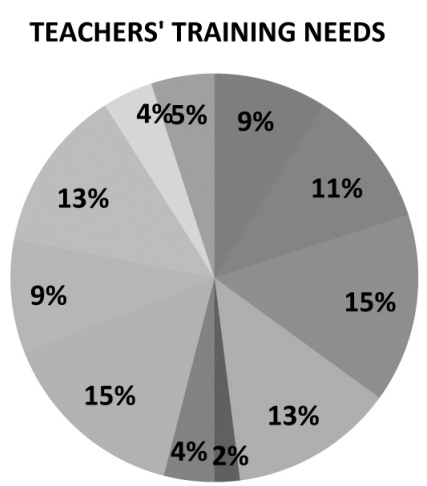
-1. Need to improve foreign language
= 2. Need for ESP training
$\because 3$. Need to improve oral comprehension
$\square$ 4. Need to improve oral production
$\square$. Need to improve written comprehension
-6. Need to improve written production
घ. Need for oral classroom language
$=8$. Need for training in the design of teaching materials
$\square$ 9. Need for training on specific methodological techniques
10 . Need for training on digital resources
$=11$. Need for training on virtual teaching

\section{Source: Own elaboration}

Considering the demands of the lecturers, and according to the regulations of the Plan, they were offered two options:

1. Attending lessons at the University Language Centre to improve their foreign

\footnotetext{
${ }^{3}$ Complete questions of the questionnaire are available in the Appendix.
} 
language oral skills ${ }^{4}$. All the teachers were required to have a minimum B2 initial foreign language level, and only a few of them had a higher level. Then, they were involved in courses belonging to the next level, i.e. those teachers with a B2 level were attending $\mathrm{C} 1$ classes, and so on. These classes were optional and free for the staff members. In fact, the final objective was to achieve a $\mathrm{C} 1$ language level after six academic years.

2. As regards methodology, an annual teacher training programme was designed. In the first academic years, the programme was based on the collaboration of lecturers and, later, workshops and sessions included the presentation of experiences on the part of university teachers participating in the programme. Timing and content of methodological courses are described below.

\subsubsection{Contents of the teacher training programme for plurilingual teaching}

Each methodological annual course contained 15 on-site hours plus 15 online hours, whose contents are specified below:

- Module 1: General approaches to CLIL.

- Instructors: Experts on bilingual teaching programmes.

- Contents:

- Advantages of CLIL in Higher Education. Teaching strategies to facilitate comprehension.

- Believing in bilingualism and making it work in the classroom.

- Management of the multilingual classroom: experiences, strategies and challenges.

- Implementing bilingual degrees in Engineering: experience.

- Challenges of English-Medium Instruction in university lectures.

- Basic interpersonal communication skills for CLIL: Teaching "real English" in the bilingual classroom.

- Module 2: Planning and Assessment.

- Instructors: Experts on bilingual teaching programmes.

- Contents:

- Lesson planning.

- Implementing and evaluating written tasks in the bilingual classroom.

- Material design.

- Module 3: Materials and resources.

- Instructors: Experts on bilingual teaching programmes.

- Contents:

\footnotetext{
${ }^{4}$ In this case, English, as it was the only foreign language used by the lecturers participating in the Plan during the academic years under study.
} 
María del Mar Sánchez and María Sagrario Salaberri Implementing Plurilingualism in Higher...

- Adapting teaching materials.

- Use of ICTs in bilingual higher education.

- Use of E-PEL or Europass.

- Module 4: Experiences in plurilingual classrooms.

- Instructors: UAL Plurilingualism staff members.

- Contents:

- Classroom experiences (Business Administration).

- Teaching in English to classes with a high number of students: alternatives to facilitate participation and communication (Business Administration).

- Practising and learning a clinical procedure through CLIL methodology (Nursing and Physiotherapy).

- Challenges in the bilingual learning of irrigation and fluid mechanics engineering (Industrial Engineering).

- Experiences in the planning and implementation of subjects within the Plurilingualism Promotion Plan (Education).

- Module 5: Resources and strategies.

- Instructors: UAL Plurilingualism staff members.

- Contents:

- Using virtual tools (Agricultural Engineering, Business Administration, Computer Engineering, and Psychology).

- Resources and strategies to develop proactive teaching material in the bilingual lab (Chemistry).

- Design and use of educational resources to promote interaction when working in small groups in Science (Chemistry).

- Finding resources for teaching in English and enhancing student involvement and participation (Business Administration).

\subsection{Results of the evaluation of the Plurilingualism Promotion Plan}

As for the evaluation of the development of the Plan, as can be observed in Table 1, the percentage of items which improved from the first analysis (2011/2012) to the second one (2014/2015) amounted to $37.5 \% .56 .3 \%$ experienced no changes, and only $6.3 \%$ worsen. Among the latter, the most significant item is number 6 , in which there were no longer courses taught in a foreign language different from English. By contrast, most of the items kept in positive or improved with a high exchange rate. In particular, the items regarding the number of courses and credits taught in a foreign language increased significantly (Items $2,3,4,5,7,8)$. 
Table 1. Results of the items analysed on plurilingualism development at the University of Almeria

\begin{tabular}{|c|c|c|c|}
\hline ITEM ANALYSIS & 2011-2012 & 2014-2015 & $\begin{array}{l}\text { EXCHANGE } \\
\text { PERCENTAGE }\end{array}$ \\
\hline $\begin{array}{l}\text { Item 1. Does the institution have a multilingualism } \\
\text { plan / strategy or a foreign-language course teaching } \\
\text { programme? }\end{array}$ & YES & YES & \\
\hline $\begin{array}{l}\text { Item 2. Of all the credits offered by the institution } \\
\text { in an academic year, which proportion is taught in a } \\
\text { foreign language? }\end{array}$ & 225.1 & 427.5 & $89.92 \%$ \\
\hline $\begin{array}{l}\text { Item 3. Of all the courses offered by the institution } \\
\text { in an academic year (excluding language courses) } \\
\text { which proportion is taught completely in a foreign } \\
\text { language? }\end{array}$ & 24.0 & 80.0 & $233.33 \%$ \\
\hline $\begin{array}{l}\text { Item } 4 \text {. Of all the courses offered by the institution } \\
\text { in an academic year (excluding language courses) } \\
\text { which proportion is taught partially in a foreign lan- } \\
\text { guage? }\end{array}$ & 22.0 & 36.5 & $65.91 \%$ \\
\hline $\begin{array}{l}\text { Item 5. Of all the credits offered by the institution in } \\
\text { an academic year in a foreign language, which pro- } \\
\text { portion is taught in English? }\end{array}$ & 204.1 & 427.5 & $109.46 \%$ \\
\hline $\begin{array}{l}\text { Item 6. Of all the credits offered by the institution in } \\
\text { an academic year in a foreign language, which pro- } \\
\text { portion is taught in other languages different from } \\
\text { English? Please specify. }\end{array}$ & 21.0 & 0.0 & $-100.00 \%$ \\
\hline $\begin{array}{l}\text { Item 7. Of all the non-language degrees offered by } \\
\text { the institution in an academic, how many offer at } \\
\text { least one course taught in a foreign language? }\end{array}$ & 7.0 & 14.0 & $50.00 \%$ \\
\hline $\begin{array}{l}\text { Item 8. Of all the academic staff of the institution } \\
\text { in an academic year, which proportion teaches any } \\
\text { course in a foreign language? }\end{array}$ & 46.0 & 100.00 & $117.39 \%$ \\
\hline $\begin{array}{l}\text { Item 9. Is there any language requirement by the ac- } \\
\text { ademic staff to teach courses in a foreign language? } \\
\text { Please, specify. }\end{array}$ & YES & YES & \\
\hline $\begin{array}{l}\text { Item 10. Does the institution offer degrees taught } \\
\text { completely in a foreign language or bilingual/pluri- } \\
\text { lingual degrees? How many? }\end{array}$ & YES & YES & \\
\hline
\end{tabular}




\begin{tabular}{|l|c|c|c|}
\hline $\begin{array}{l}\text { Item 11. Of all the BA degrees offered by the institu- } \\
\text { tion in an academic year, which proportion belongs } \\
\text { to international double/joint degrees? }\end{array}$ & 0.0 & 0.0 & $0.00 \%$ \\
\hline $\begin{array}{l}\text { Item 12. Of all the postgraduate degrees offered by } \\
\text { the institution in an academic year, which proportion } \\
\text { belongs to international double/joint degrees? }\end{array}$ & 0.0 & 0.0 & $0.00 \%$ \\
\hline $\begin{array}{l}\text { Item 13. Of all the degrees offered by the institution, } \\
\text { how many foresee the development of professional } \\
\text { internships abroad? }\end{array}$ & 100.0 & 100.0 & $0.00 \%$ \\
\hline $\begin{array}{l}\text { Item 14 Is there any language requirement in the in- } \\
\text { stitution for the access or completion of studies by } \\
\text { the students? }\end{array}$ & YES & YES & YES \\
\hline $\begin{array}{l}\text { Item 15. Does the institution offer specific language } \\
\text { learning programmes for academic staff? }\end{array}$ & YES & YES & \\
\hline $\begin{array}{l}\text { Item 16. Does the institution offer any grant for lan- } \\
\text { guage training addressed to the academic staff? }\end{array}$ & YES & \\
\hline
\end{tabular}

\section{Source: Own elaboration}

\section{Discussion}

The teacher training programme designed responds to what the plurilingual lecturers demanded according to the initial teacher training needs analysis. The results of the initial questionnaire match some previous studies regarding the attitudes towards teacher training in higher education (Aguilar and Rodríguez, 2012). In their research, most of the lecturers interviewed responded that they were not interested in methodological strategies, but they preferred training in English for general and academic purposes. In our study, most of the lecturers interviewed were mostly interested in oral communicative skills development, rather than specific methodological techniques and strategies. As supported by Dafouz (2014), such findings deserve serious attention since they clearly illustrate the general attitude in plurilingual and EMI settings, where pedagogical matters are usually of secondary importance. In her words, it also reveals that "the ultimate aim for many subject teachers working in these contexts is to move forward in their career development, and English proficiency is undoubtedly a key component in this equation" (Dafouz, 2014: 3).

On the other hand, the results the programme evaluation reveal that the development of the Plurilingualism Promotion Plan at the University of Almeria improved from 2012 to 2015 according to the items analysed. Only a small percentage worsened slightly, as the offer of courses taught in additional languages different from English diminished. This may point to an increase in the importance of the English language as the main foreign language, or lingua franca, to the detriment of other alternatives. As Baker (2006) states, it could be considered a strong way of bilingual education, since the achievement of a level of functional competence in the English language is sought. In fact, it could be even noted that it 
is a sort of bilingual immersion, since it is applied to those programmes in which, at least, $50 \%$ of curricular content is taught through the medium of English as a foreign language (Swain and Johnson, 1997; Swain and Lapkin, 2005). As the results of this study show, in the items related to this field, a high percentage of courses taught in English is observed.

\section{Conclusions}

This study has provided a description of the design of a teacher training programme for plurilingual teaching, as well as an evaluation of the development of a Plurilingualism Promotion Plan implemented at an Andalusian university, following the guidelines of the Council of Europe to promote language learning and linguistic diversity to stimulate all students to learn languages and offer them the possibility of studying abroad.

The findings show a training programme designed according to the needs reported by the lecturers, who showed to be more interested in language communicative skills - particularly, oral skills - than in methodology. These results show the general attitude towards plurilingual teaching in higher education, where the main issue found at this level lies on the need to improve the language proficiency of the faculty staff.

Furthermore, the analysis of the evaluation of the programme reveals that the majority of the items analysed improved in the second period of analysis, especially those regarding the increase of the number of English-taught subjects and ECTS to the detriment of other foreign languages, which ratifies the hegemony of English as the main foreign language used in plurilingual courses at this university.

This study might inspire further higher education institutions in the design and implementation of plurilingual and teacher training programmes due to the lack of administrative regulations on the matter, as well as the current scarce descriptive data available on university plurilingual plan development in Andalusia and Spain.

\section{RefERENCES}

Aguilar, M. \& Rodríguez, R. (2012). "Lecturer and student perceptions on CLIL at a Spanish university", in International Journal of Bilingual Education and Bilingualism, 15, 2: 183-197.

Altbach, P.G. \& Knight, J. (2007). "The Internationalisation of Higher Education: Motivations and Realities", in Journal of Studies in International Education, 11: 290-305.

Arnold, W. (2010). "Where is Clil taking us?", in Pulso, 33: $227 \square 233$.

Baker, C. (2006). Foundations of Bilingual Education and Bilingualism. Clevedon: Multilingual Matters.

Ballesteros, F.J. (2009). "La enseñanza de lenguas en el espacio europeo de educación superior", in Avances en Supervisión Educativa, 10. Available from: http://www.adide.org/ revista/ images/stories/pdf_10/ase10_monog06.pdf, accessed 2 September, 2016.

Coleman, J. (2006). "English-medium teaching in European higher education", in Language Teaching, 39, 1: 1-14.

Costa, F. \& Coleman, J.A. (2010). "Integrating content and language in higher education in Italy: 
María del Mar Sánchez and María Sagrario Salaberri Implementing Plurilingualism in Higher...

Ongoing research", in International CLIL Research Journal, 1, 3: 19-29.

Council of Europe (2001). Common European Framework of Reference for Languages (CEFR): Learning, Teaching, Assessment. Modern Languages Division. Strasbourg. Cambridge University Press.

Council of Europe (2003). Guide for the Development of Language Education Policies in Europe: From Linguistic Diversity to Plurilingual Education. Available from http://www.coe.int/t/ dg4/linguistic/Source/FullGuide_EN.pdf, accessed 15 June, 2016.

Coyle, D., Hood, P. \& Marsh, D. (2010). CLIL: Content and Language Integrated Learning. Cambridge: Cambridge University Press.

Dafouz, E. (2014). "Integrating content and language in European higher education: An overview of recurrent research concerns and pending issues", in P. Joycey, E. Agathopoulou and M. Mattheoudakis (eds), Cross-Curricular Approaches to Language Education. Cambridge: Cambridge Scholars Publishing, 289-304.

Dafouz, E., Núñez, B., Sancho, C. \& Foran D. (2007). "Integrating CLIL at the tertiary level: teachers' and students' reactions", in D. Wolff \& D. Marsh (eds.), Diverse Contexts Converging Goals. Content and Language Integrated Learning in Europe. Frankfurt, Germany: Peter Lang, 91-102.

Dafouz, E. \& Smit, U. (2016). "Towards a dynamic conceptual framework for English medium education in multilingual university settings", in Applied Linguistics, 37, 3: 397-415.

Dalton-Puffer, C., Nikula, T. \& Smit, U. (2010). Language Use and Language Learning in CLIL Classrooms. Amsterdam: John Benjamins.

Doiz, A., Lasagabaster, D. \& Sierra, J.M. (2013). English-Medium Instruction at Universities: Global Challenges. London: British Library.

Escobar, C. \& Nussbaum, L. (eds). (2011). Aprendre en una altra llengua / Learning through another language. Bellaterra, Barcelona, Spain: Servei de publicacions UAB.

European Commission (2015). Erasmus + Programme Guide. Available from: http://ec.europa.eu/ programmes/erasmus-plus/discover/guide/index_es.htm, accessed 15 April, 2016.

Fortanet, I. (2013). Multilingualism in Higher Education: Towards a Multilingual Language Policy. London: Multilingual Matters.

Gonçalves, M.L.S. (2011). Desenvolvimento profissional e educação em línguas: potencialidades e constrangimentos em contexto escolar. PhD Thesis. Aveiro: Universidade de Aveiro.

Grimshaw, T. (2007). "Critical perspectives on language in international higher education", in M. Hayden, J. Levy \& J. Thompson (eds.), The Sage Handbook of Research in International Education. London: Sage, 365 - 378.

Hellekjaer, G.O. \& Wilkinson, R. (2001). "Content and Language Integrated Learning (CLIL) in Higher Education: An issue-raising workshop”, in F. Mayer (Ed.), Language for Special Purposes Perspectives for the New Millennium. Tubingen: Narr, 398-408.

Junta de Andalucía, (2005). Plan de Fomento del Plurilingüismo. Consejería de Educación. Available from: http://www.juntadeandalucia.es/, accessed 30 November, 2016.

Lasagabasgter, D. (2013). "Attitudes and motivation in bilingual education", in C.A. Chapelle (Ed.), The Encyclopaedia of Applied Linguistics. Oxford: Wiley Blackwell.

Lasagabaster, D. \& Ruiz de Zarobe, Y. (eds.) (2010). CLIL in Spain. Implementation, Results and Teacher Training. Newcastle upon Tyne: Cambridge Scholars Publishing.

Llinares, A. \& Whittaker, R. (2006). "Oral and written production in social science. Current Research on CLIL", in VIEWS, 15, 3, 28-32.

Lorenzo, F., Casal, S. \& Moore, P. (2010). "The Effects of Content and Language Integrated Learning in European Education: Key Findings from the Andalusian Bilingual Sections Evaluation Project", in Applied Linguistics, 31, 3: 418-442. 
Madrid, D. \& Hughes, S. (eds.) (2011). Studies in Bilingual Education. Bern: Peter Lang.

Manzano, F., Sánchez-Pérez, M.M. \& Salaberri, M.S. (2012). "Bilingualism in Engineering Curricula at CEIA3 Universities". IATED Conference. 18-21 November, Valencia, Spain. Available from: https://library.iated.org/view/MANZANOAGUGLIARO2012BIL, accessed 20 March, 2016.

Marsh, D. (2002). CLIL/EMILE - The European dimension. Actions, trends and foresight potential. Strasbourg: European Commission.

Moore, D. \& Gajo, L. (2009). "Introduction. French Voices on Plurilingualism and Pluriculturalism. Theory, Significance and Perspective", in International Journal of Multilingualism, 6, 2: 137-153.

Morgado, M. \& Coelho, M. (2013). "CLIL vs English as the medium of instruction: The Portuguese higher education Polytechnic context”, in Egitania Sciencia 12: 123-45.

Nancy Declaration (2006). Multilingual Universities for a Multilingual Europe Open to the World. Available from: https://www0.sun.ac.za/taalsentrum/assets/files/Nancy\%20Declaration.pdf, accessed 20 January, 2017.

Pavón, V. \& Gaustad, M. (2013). "Designing bilingual programmes for higher education in Spain: Organisational, curricular and methodological decisions", in International CLIL Research Journal, 2, 1: 82 -94.

Pavón, V. \& Rubio, F. (2010). "Teachers' concerns about the introduction of CLIL programmes", in Porta Linguarum, 14: 45-58.

Pérez-Cañado, M.L. (2013). Competency-based Language Teaching in Higher Education. Amsterdam: Springer.

Pérez-Vidal, C. (ed.) (2014). Language Acquisition in Study Abroad and Formal Instruction Contexts. Amsterdam/Philadelphia: John Benjamins Publishing Company.

Pinto, S. \& Araújo e Sá, M.H. (2015). "Language learning in higher education: Portuguese student voices", in International Journal of Multilingualism, 13, 3: 367-382.

Ramos, A.M. (2013). "Higher education bilingual programmes in Spain", in Porta Linguarum, 19: 101-111.

Rubio, F.D. \& Hermosín, M.J. (2010). "Implantación de un programa de plurilingüismo en el espacio europeo de educación superior: Análisis de contexto y detección de necesidades", in XXI, Revista de Educación, 12: 107-128.

Salaberri, M.S. \& Sánchez-Pérez, M.M. (2012). “CLIL lesson planning”, in J. Martínez Agudo (Ed.), Teaching and Learning English trough Bilingual Education. Newcastle: Cambridge Scholars Publishing, 89-110.

Sánchez-Pérez, M.M. \& Manzano, F. (2012). "Methodologies in bilingual teaching at ceiA3 universities from a student and professor's perspective", in F. Manzano \& A. García (eds.), Propuesta de Actividades y Metodologías Especificas para la Mejora del Bilingüismo en Ingeniería. Universidad de Almería: Servicio de Publicaciones, 51-64

Smit, U. \& Dafouz, E. (2012). "Integrating content and language in higher education. Gaining insights into English-medium instruction at European universities", AILA Review, 25. Philadelphia, PA: John Benjamins.

Smith, K. (2004). "Studying in an additional language: What is gained, what is lost and what is assessed?", in R. Wilkinson (Ed.), Integrating Content and Language: Meeting the Challenge of a Multilingual Higher Education. Maastricht: Universitaire pers, 78-93. 
María del Mar Sánchez and María Sagrario Salaberri Implementing Plurilingualism in Higher...

Snow, M.A. \& Brinton, D.M. (1997). The Content-Based Classroom. Washington: Georgetown University Press.

Swain, M. and R.K. Johnson (1997) "Immersion education: a category within bilingual education", in R.K. Johnson \& M. Swain (eds.), Immersion education: international perspectives. Cambridge University Press, 1-16.

Swain, M. \& Lapkin, S. (2005). "The evolving sociopolitical context of immersion education in Canada: some implications for program development", in International Journal of Applied Linguistics, 15, 2: 169-186.

Toledo, I., Rubio, F.D. \& Hermosín, M. (2012). "Creencias, rendimiento académico y actitudes de alumnos universitarios principiantes en un programa plurilingüe", in Porta Linguarum, 18: 213-229.

Van Damme, D. (2001). "Higher Education in the Age of Globalisation: The Need for a New Regulatory Framework for Recognition, Quality assurance and Accreditation”. UNESCO Expert Meeting, 10-11 September. Paris, France.

Varghese, N.V. (2008). Globalisation of Higher Education and Cross-border Student Mobility. Paris: UNESCO and IIEP.

Vilkanciené, L. (2011). "CLIL in tertiary education: Does it have anything to offer?", in Studies About Languages, 18: 111-116

Weber, L.E. \& Duderstadt, J.J. (2008). The Globalization of Higher Education. Switzerland: University of Geneva.

Wilkinson, R. \& Zegers, V. (2007). Researching Content and Language Integration in Higher Education. Maastricht: Universitaire Pers Maastricht. 


\section{Appendix}

Questionnaire on staff training needs.

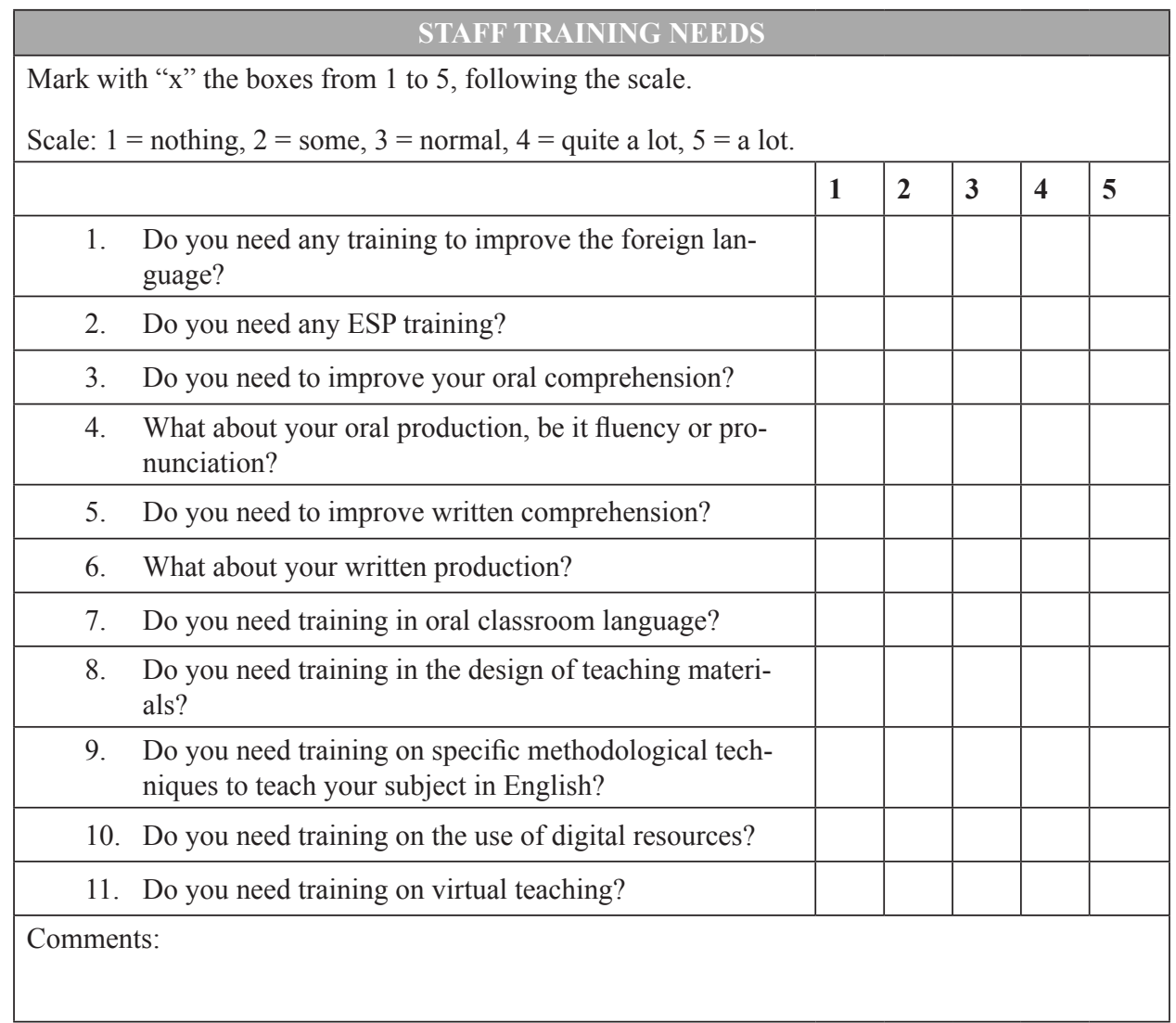

